\title{
ANALISA LAPORAN KEUANGAN CV. DUNIA WARNA KARANGANYAR TAHUN 2012-2014
}

\author{
ELLISA dan SUPRIHATI \\ STIE AAS Surakarta \\ Email:suprihati18@gmail.com
}

\begin{abstract}
ABSTRAK
Analisis rasio laporan keuangan yang lazim digunakan adalah analisis rasio likuiditas atau rasio modal kerja, analisis rasio solvabilitas, dan analisis rasio rentabilitas/profitabilitas. Analisis rasio likuiditas merupakan rasio yang digunakan untuk mengukur kemampuan perusahaan dalam memenuhi kewajiban jangka pendek perusahaan. Analisis rasio solvabilitas merupakan rasio untuk mengukur kemampuan perusahaan dalam memenuhi kewajiban jangka panjang perusahaan. Analisis rasio rentabilitas/profitabilitas merupakan rasio yang digunakan untuk mengukur kemampuan perusahaan dalam menghasilkan laba yang dihasilkan dari penjualan. Untuk mengetahui kondisi laporan keuangan pada CV. Dunia Warna pada tahun 2012-2014, mengetahui analisa rasio keuangan pada CV. Dunia Warna pada tahun 2012-2014. dan manfaat dari analisa rasio laporan keuangan untuk menilai kinerja keuangan pada CV. Dunia Warna. Current Ratio periode 2012-2014 perusahaan di atas 200 \% maka berarti aktiva lancar pada setiap tahunnya dapat menjamin seluruh hutang lancar yang di milikinya. Perusahaan dapat memenuhi kewajiban jangka pendeknya. Quick Ratio yang dihasilkan perusahaan berada di atas $100 \%$, berarti aktiva lancar dikurangi persediaan dapat menjamin seluruh hutang lancarnya. Dengan quick ratio di atas $100 \%$ maka suatu perusahaan sudah bisa di katakan likuid. Total Debt to Equity Ratio , Times Interest Earned Ratio, dan Total Debt to Total Capital Assets Ratio pada perusahaan ini mengalami kenaikan maka dapat di katakan perusahaan tersebut solvabel, karena perbandingan jumlah hutang dengan total modal dan total aktiva sangat tinggi, maka solvabilitas perusahaan sudah mampu untuk memenuhi kewajiban jangka panjang pada perusahaan tersebut. Net Earning Power Ratio menunjukkan perusahaan mampu menginvestasikan aktiva, karena rasio mengalami peningkatan. Rate of Return for the Owner menunjukkan bahwa perusahaan mampu menghasilkan laba dari modal sendiri yang dimiliki karena secara keseluruhan rasio mengalami peningkatan. Net Profit Margin menunjukkan bahwa perusahaan mampu menghasilkan laba dari penjualan bersih, karena rasio mengalami peningkatan. Gross Profit Margin on Sales menunjukkan bahwa perusahaan mampu menghasilkan sedikit laba dari penjualan,karena prosentase rasionya mengalami penurunan.Basic Earning Power Ratio menunjukkan bahwa perusahaan dapat menciptakan EBIT dengan jumlah yang sedikit.
\end{abstract}

Kata kunci : Likuiditas, Solvabilitas, Profitabilitas 


\section{PENDAHULUAN}

Pertumbuhan ekonomi Indonesia pada sebuah perusahaan merupakan salah satu tanggung jawab akuntan. Dengan demikian diharapkan perusahaan dapat bertahan dan bersaing dengan perusahaan sejenis lainnya di pasaran. Perusahaan harus disusun sesuai kemampuan dan perkembangan yang dimiliki agar pelaksanaannya dapat berjalan dengan baik dan lancar. Perkembangan suatu usaha konsolidasi suatu perusahaan dapat dilihat dari data keuangan perusahaan tersebut yang berisi informasi mengenai posisi keuangan serta hasil yang telah dicapai selama periode tertentu.

Manajemen keuangan sangat berpengaruh terhadap kelangsungan kegiatan dan eksistensi suatu perusahaan, selain itu manajemen keuangan juga berpengaruh pada setiap individu yang ada dalam perusahaan tersebut. Oleh karena itu seorang manajer keuangan dituntut untuk dapat menjalankan manajemen keuangan dengan baik, hal tersebut dilakukan agar suatu perusahaan dapat melaksanakan kegiatan operasional perusahaan dengan lebih efisien dan efektif, sehingga perusahaan dapat mempertahankan dan mengembangkan aktivitas serta keberadaan perusahaan.

Selain manajemen yang baik, dalam suatu perusahaan juga memerlukan analisis terhadap laporan keuangan perusahaan tersebut. Analisis rasio keuangan dapat membantu para pelaku bisnis, pihak pemerintah dan para pemakai laporan keuangan lainnya dalam menilai kondisi keuangan suatu perusahaan. Meskipun laporan keuangan adalah suatu hasil dari proses akuntansi yang disajikan dalam bentuk kualitatif dimana informasi-informasi yang diberikan dapat membantu dalam pengambilan keputusan bagi perorangan maupun perusahaan. Laporan keuangan yang terdiri atas neraca, laporan laba rugi, laporan perubahan ekuitas, catatan atas laporan keuangan, laporan perubahan modal serta laporan arus kas.

Dengan menggunakan rasio keuangan untuk menganalisa pos-pos neraca akan dapat diketahui atau diperoleh gambaran posisi keuangan perusahaan, sedangkan analisa terhadap laporan laba rugi akan memberikan gambaran tentang hasil dan perkembangan perusahaan. Laporan keuangan pada umumnya digunakan secara luas oleh pihak intern maupun oleh pihak ekstern perusahaan. Pihak intern adalah pihak yang membutuhkan informasi dari hasil analisis laporan keuangan untuk membantu mereka dalam mengelola, merencanakan, dan mengendalikan kegiatan perusahaan. Pihak intern suatu perusahaan terdiri dari manajemen perusahaan, para pembuat keputusan di perusahaan, dan staff di perusahaan tersebut. Keputusan yang diambil oleh pihak intern akan secara langsung mempengaruhi kegiatan pada perusahaan tersebut. Pihak ekstern terdiri dari para investor, kreditur, pemerintah, dan masyarakat umum.

Pentingnya dalam menganalisa suatu laporan keuangan secara menyeluruh adalah untuk melihat perbandingan saldo-saldo yang dipandang berkaitan, yang dapat 
mencerminkan posisi keuangan perusahaan serta kinerja perusahaan tersebut seperti bagaimana likuiditas keuangan perusahaan tersebut, kemampuan perusahaan tersebut dalam melunasi utangnya serta kemampuan perusahaan tersebut dalam menghasilkan laba dan hal lainnya, baik itu merupakan suatu kemajuan ataupun suatu kemunduran. Perbandingan inilah yang lebih dikenal dengan istilah rasio.

Analisis rasio laporan keuangan yang lazim digunakan adalah analisis rasio likuiditas atau rasio modal kerja, analisis rasio solvabilitas, dan analisis rasio rentabilitas/profitabilitas. Analisis rasio likuiditas merupakan rasio yang digunakan untuk mengukur kemampuan perusahaan dalam memenuhi kewajiban jangka pendek perusahaan. Analisis rasio solvabilitas merupakan rasio untuk mengukur kemampuan perusahaan dalam memenuhi kewajiban jangka panjang perusahaan. Analisis rasio rentabilitas/profitabilitas merupakan rasio yang digunakan untuk mengukur kemampuan perusahaan dalam menghasilkan laba yang dihasilkan dari penjualan.

\section{Tujuan}

1. Untuk mengetahui kondisi laporan keuangan pada CV. Dunia Warna pada tahun 2012-2014.

2. Untuk mengetahui analisa rasio keuangan pada CV. Dunia Warna pada tahun 20122014.

3. Untuk mengetahui manfaat dari analisa rasio laporan keuangan untuk menilai kinerja keuangan pada CV. Dunia Warna.

\section{KAJIAN PUSTAKA}

Ada beberapa definisi laporan keuangan yang dikemukakan oleh para ahli yaitu :

a. Laporan Keuangan juga melaporkan prestasi historis dari suatu perusahaan dan memberikan dasar, bersama dengan analisis bisnis dan ekonomi, untuk membuat proyeksi dan peramalan untuk masa depan Laporan keuangan adalah laporan yang memuat hasil-hasil perhitungan dari proses akuntansi yang menunjukkan kinerja keuangan suatu perusahaan pada suatu saat tertentu (Weston, dkk, 1994:24)

b. Laporan keuangan adalah media yang dapat dipakai unluk meneliti kondisi kesehatan perusahaan yang terdiri dari neraca, perhitungan laba rugi, ikhtisar laba ditahan, dan laporan posisi keuangan (Sawir, 2001:2)

c. Laporan keuangan merupakan hasil dari proses akuntansi, yang meliputi neraca, perhitungan rugi laba dan laba vang ditahan. laporan perubahan posisi keuangan serta catatan atas laporan keuangan (Harnanto, 1987:9)

d. Laporan keuangan adalah laporan keuangan pada dasarnya adalah hasil dari proses akuntansi yang dapat digunakan sebagai alat untuk berkomunikasi antara data keuangan atau aktivitas suatu perusahaan dengan pihak-pihak yang berkepentingan dengan/atau aktivitas perusahaan tersebut (Munawir, 2000:2)

e. Laporan Keuangan adalah laporan yang menunjukan kondisi keuangan perusahaan pada saat ini atau dalam suatu periode tertentu (Kasmir, 2008:5) 
f. Laporan Keuangan adalah output dan hasil dari proses akuntansi yang menjadi bahan informasi bagi para pemakainya sebagai salah satu bahan dalam proses pengambilan keputusan (Harahap, 2007:10)

\section{Jenis Rasio Keuangan}

Jenis analisa rasio keuangan sebagai berikut :

a. Rasio Likuiditas

Rasio ini berguna untuk mengukur perusahaan untuk memenuhi kewajiban-kewajiban jangka pendeknya.
1) Current Ratio (Rasio Lancar)

Menunjukkan sejauh mana aktiva lancar menutupi kewajibankewajiban lancar. Semakin besar perbandingan-perbandingan aktiva lancar dengan hutang lancar, semakin tinggi kemampuan perusahaan untuk menutupi kewajiban jangka pendeknya. Apabila rasio lancar ini $100 \%$ berarti aktiva lancar dapat menutupi semua hutang lancar.

Aktiva Lancar

Rasio Lancar $=\frac{}{\text { Utang Lancar }} \times 100 \%$

Rasio lancar yang rendah biasanya dianggap menunjukkan terjadinya masalah dalam likuiditas. Sebaliknya suatu perusahaan yang rasio lancarnya terlalu tinggi juga kurang bagus, karena menunjukkan banyaknya dana menganggur yang pada akhirnya dapat mengurangi

2) Acid Test Ratio / Quick Ratio

Quick Ratio atau rasio cepat yaitu menunjukkan kemampuan perusahaan untuk memenuhi hutang-hutangnya tanpa perhitungan persediaannya. kemampulabaan perusahaan.

$$
\text { Acid Test Ratio }=\frac{\text { Aktiva Lancar }- \text { Persediaan }}{\text { Utang Lancar }} \times 100 \%
$$

b. Rasio Solvabilitas

Rasio ini berguna untuk mengukur kemampuan perusahaan untuk memenuhi seluruh kewajiban-kewajibannya (hutang jangka pendek dan hutang jangka panjang). 
Yang termasuk ratio solvabilitas adalah :

1) Rasio Utang atas Modal

Rasio ini menggambarkan sampai sejauh mana modal pemilik dapat menutupi hutang-hutang kepada pihak luar. Semakin kecil rasio ini semakin baik. Rasio ini disebut juga rasio Leverage. Untuk keamanan pihak luar rasio terbaik jika jumlah modal lebih besar dari jumlah utang atau minimal sama. Namun bagi pemegang saham atau manajemen rasio leverage ini sebaiknya besar.
2) Times interest earned ratio / Interest Coverage

Times interest earned ratio atau Interest converage, rasio ini
Rasio Utang Atas Modal $=\frac{}{\text { Modal (Equity) }} \times 100 \%$

E B I T

Times interest earned ratio $=\frac{}{\text { Beban Bunga }} \times 100 \%$ bertujuan untuk mengukur pengaruh beban bunga terhadap laba sebelum bunga dan pajak (EBIT).

Analisis rasio digunakan secara khusus oleh investor dan kreditor dalam keputusan investasi atau penyaluran dana. Selain itu rasio keuangan dapat berfungsi sebagai alat untuk mendeteksi awal masalah yang terjadi didalam perusahaan, terutama berkaitan dengan masalah keuangan.

3) Rasio Utang atas Aktiva

Rasio ini menunjukkan sejauhmana utang dapat ditutupi oleh aktiva lebih besar rasionya lebih aman (solvabel). Bisa juga dibaca berapa porsi utang dibanding dengan aktiva. Supaya aman porsi utang terhadap aktiva harus lebih kecil.

Rasio Utang atas Aktiva $=\frac{\text { Total Hutang }}{\text { Total Aktiva }} \times 100 \%$ 
c. Rasio Rentabilitas/Profitabilitas

Rasio Rentabilitas/Profitabilitas adalah rasio yang menunjukkan besarnya laba yang diperoleh sebuah perusahaan dalam periode tertentu. Rasio ini digunakan untuk menilai seberapa efisien pengelola perusahaan dapat mencari keuntungan atau laba untuk setiap penjualan yang dilakukan.

Rasio ini merupakan ukuran yang menunjukkan kemampuan perusahaan dalam melakukan peningkatan penjualan dan menekan biaya-biaya yang terjadi. Selain itu, rasio ini menunjukkan kemampuan perusahaan dalam memanfaatkan seluruh dana yang dimilikinya untuk mendapatkan keuntungan maksimal.

Rasio Untuk Menghitung Rentabilitas/Profitabilitas : Gross Margin of Sales, Margin Laba Kotor atas Penjualan. Gross Margin on Sales biasa juga disebut sebagai Gross Margin Ratio, Margin Laba Kotor atau Margin Laba Kotor atas Penjualan. Pada dasarnya Rasio ini menunjukkan nilai relative antara nilai laba kotor terhadap nilai penjualan. Laba kotor adalah nilai penjualan dikurangi harga pokok penjualan. Formula untuk menghitung

1) Gross Profit Margin on Sales adalah sebagai berikut :

\section{Penjualan - Harga Pokok Penjualan}
Gross Profit Margin on Sales $=$
Penjualan

Net Profit Margin/ Margin Laba Bersih. Rasio Margin Laba Bersih atau net profit margin ratio menunjukkan nilai relative antara nilai keuntungan setelah bunga dan pajak dengan total penjualan.
Rasionya dihitung dengan membagi nilai laba setelah bunga dan pajak dengan total penjualan. Rumus untuk menghitung rasio

2) Margin Laba Bersih adalah :

a) Gross Margin Ratio

$$
\text { Gross Margin Ratio }=\frac{\text { Laba Kotor }}{\text { Penjualan }} \times 100 \%
$$


b) Operating Margin Ratio

$$
\text { Operating Margin Ratio }=\frac{\text { Laba Usaha }}{\text { Penjualan }} \times 100 \%
$$

c) Rasio Rentabilitas Modal Sendiri

$$
\text { Rasio Rentabilitas Modal Sendiri }=\frac{\text { Earning AfterTax }}{\text { Modal Sendiri }} \times 100 \%
$$

d) Rasio Marjin Laba Bersih (Profit Margin on Sales Ratio)

$$
\text { Rasio Marjin Laba Bersih }=\frac{\text { Laba Bersih }}{\text { Penjualan }} \times 100 \%
$$

e) Rasio Daya Laba Dasar (Basic Earning Power Ratio)

$$
\text { Rasio BEP }=\frac{\text { E B I T }}{\text { Total Aktiva }} \times 100 \%
$$

f) Rasio Pengembalian Atas Total Aktiva atau ROA (Return on Assets Ratio) atau ROI (Return on Investment)

$$
\text { Rasio ROI }=\frac{\text { Laba Bersih }}{\text { Total Aktiva }} \text { 100\% }
$$

g) Rasio Pengembalian Atas Ekuitas atau ROE

$$
\text { Rasio ROE }=\frac{\text { Laba Bersih }}{\text { Ekuitas }} \times 100 \%
$$




\section{PEMBAHASAN}

\section{A. Analisis Rasio Likuiditas}

Merupakan Rasio yang bertujuan untuk mengetahui kemampuan perusahaan dalam memenuhi kewajiban jangka pendek.

1. Current Ratio ( Rasio Lancar )
Menurut Syahyunan (2011:84) menyatakan Current Ratio yaitu kemampuan aktiva lancar perusahaan dalam memenuhi kewajiban jangka pendek dengan aktiva lancar yang dimiliki.

Tabel .1

Perhitungan Rasio Lancar (Current Ratio)

\begin{tabular}{|c|c|c|c|}
\hline Tahun & Aktiva Lancar & Hutang Lancar & Rasio Lancar \\
\hline 2012 & 770.500 .000 & 302.713 .000 & $255 \%$ \\
\hline 2013 & 801.600 .000 & 300.750 .000 & $267 \%$ \\
\hline 2014 & 905.250 .000 & 329.775 .000 & $275 \%$ \\
\hline
\end{tabular}

Berdasarkan tabel .1 di atas menjelaskan perhitungan Rasio Lancar (Current Ratio). Aktiva Lancar tahun 2012 Rp 770.500.000,- tahun 2013 Rp 801.600.000,- tahun $2014905.250 .000,-$. Hutang Lancar tahun 2012 Rp 302.713.000,- tahun $2013 \quad \mathrm{Rp}$ 300.750.000,- tahun $2014 \quad \mathrm{Rp}$ 329.775.000,-

Terjadi kenaikan setiap tahunnya dari tahun 2012 ke 2014. Tahun 2012 sebesar $255 \%$ pada tahun 2013 sebesar $267 \%$ sedangkan pada tahun 2014 sebesar $275 \%$

Dapat diketahui bahwa Rasio Lancar perusahaan ditahun 2014 cukup baik, karena kemampuan perusahaan dalam melunasi hutang lancarnya dengan seluruh aktiva lancarnya 2,75 kali. Artinya Rp 1,hutang lancar dijamin dengan Rp 2,75,aktiva lancar. Semakin besar rasio ini semakin baik, karena mencerminkan keadaan likuiditas perusahaan.

Rasio Lancar di tahun 2014 mengalami peningkatan dibandingkan dengan tahun 2013. Peningkatan ini disebabkan karena kenaikan aktiva lancar sebesar Rp 103.650.000,- lebih besar daripada kenaikan hutang lancarnya yang sebesar Rp 29.025.000,- . 
2. Acid Test Ratio/ Quick Ratio (Ratio Cepat)

Menurut Syahyunan (2011:84) mengukur kemampuan aktiva lancar dikurangi persediaan untuk membayar kewajiban lancar.

menyatakan rasio ini digunakan untuk

$$
\text { Rasio Cepat }=\frac{\text { Aktiva Lancar }- \text { Persediaan }}{\text { Hutang Lancar }} \times 100 \%
$$

Tabel .2

Perhitungan Rasio Cepat (Quick Ratio)

\begin{tabular}{|c|c|c|c|c|}
\hline Tahun & Aktiva Lancar & Persediaan & Hutang Lancar & Rasio Cepat \\
\hline 2012 & 770.500 .000 & 379.280 .000 & 302.713 .000 & $129 \%$ \\
\hline 2013 & 801.600 .000 & 556.300 .000 & 300.750 .000 & $82 \%$ \\
\hline 2014 & 905.250 .000 & 750.500 .000 & 329.775 .000 & $47 \%$ \\
\hline
\end{tabular}

Berdasarkan tabel 2 di atas menjelaskan perhitungan Rasio Cepat (Quick Ratio). Aktiva Lancar tahun 2012 Rp 770.500.000,- , tahun 2013 Rp 801.600.000,- tahun $2014 \quad \mathrm{Rp}$ 905.250.000. Persediaan tahun $2012 \mathrm{Rp}$ 379.280.000,- $\quad$ tahun $2013 \quad \mathrm{Rp}$ 556.300.000,- $\quad$ tahun $2014 \quad \mathrm{Rp}$ 750.500.000,- Hutang Lancar tahun 2012 Rp 302.713.000,- tahun 2013 Rp 300.750.000,- $\quad$ tahun $2014 \quad \mathrm{Rp}$ 329.775.000,- .

Rasio cepat dari tahun 2012-2014 mengalami penurunan, tahun 2013 mengalami penurunan sebesar 0,47 kali dari tahun 2012, sedangkan tahun 2014 mengalami penurunan sebesar 0,35 kali dari tahun 2013. Berdasarkan tabel di atas dapat dilihat bahwa Quick Ratio CV. Dunia Warna periode 2012-2014 menunjukkan kemampuan perusahaan untuk memenuhi kewajiban jangka pendeknya kurang baik, karena dari tahun 2012-2014 terus mengalami penurunan.

\section{B. Rasio Solvabilitas}

Merupakan rasio yang digunakan untuk mengetahui kemampuan perusahaan untuk memenuhi seluruh kewajibankewajibannya (hutang jangka pendek dan jangka panjang) jika perusahaan tersebut di likuidasi.

\section{Rasio Utang atas Modal ( Total Debt to Equity Ratio )}

Menurut Syahyunan ( 2004:84 ) meruapakan rasio yang menunjukkan presentase penyediaan dana oleh pemegang saham terhadap pemberi pinjaman. Semakin tinggi rasio semakin 


$$
\text { Rasio Utang Atas Modal }=\frac{\text { Total Hutang }}{\text { Modal (Equity) }} \times 100 \%
$$

Tabel .3

\section{Perhitungan Rasio Hutang Atas Modal}

\begin{tabular}{|l|l|l|l|}
\hline \multicolumn{1}{|c|}{ Tahun } & \multicolumn{1}{|c|}{ Total Hutang } & \multicolumn{1}{|c|}{ Modal } & \multicolumn{1}{c|}{$\begin{array}{c}\text { Rasio Hutang } \\
\text { Atas Modal }\end{array}$} \\
\hline 2012 & 302.713 .000 & 823.874 .000 & $36,74 \%$ \\
\hline 2013 & 300.750 .000 & 866.920 .000 & $34,69 \%$ \\
\hline 2014 & 329.775 .000 & 961.947 .000 & $34,32 \%$ \\
\hline
\end{tabular}

Berdasarkan tabel .3 di atas menjelaskan perhitungan Rasio Hutang Atas Modal. Total Hutang tahun $2012 \mathrm{Rp}$ 302.713.000,- , tahun $2013 \mathrm{Rp}$ 300.750.000,- , tahun $2014 \mathrm{Rp}$ 329.775.000,- . Modal tahun $2012 \mathrm{Rp}$ 823.874.000,- , tahun 2013 Rp 866.920.000,- $\quad, \quad$ tahun $2014 \quad \mathrm{Rp}$ 961.947.000,-

Pada tahun 2012 rasio hutang atas modal sebesar 36,74 \% yang diperoleh dari perbandingan total hutang sebesar Rp 302.713.000,- dengan modal sebesar Rp 823.874.000,- . Pada tahun 2013 rasio hutang atas modal sebesar 34,69\% yang diperoleh dari perbandingan total hutang sebesar Rp 300.750.000,- dengan modal sebesar Rp 866.920.000,- . Pada tahun
2014 rasio hutangnya 34,32 \% yang diperoleh dari perbandingan total hutang Rp 329.775.000,- dengan modal sebesar Rp 961.947.000,- .

Pada tahun 2013 terjadi penurunan dari $36,74 \%$ pada tahun 2012 menjadi sebesar 34,69 \%. Pada tahun 2014 juga terjadi penurunan dari $34,69 \%$ pada tahun 2013 menjadi sebesar $34,32 \%$.

Berdasarkan tabel di atas dapat dilihat bahwa Total Debt to Equity Ratio pada CV. Dunia Warna periode 20122014 rasionya mengalami penurunan dari tahun ke tahun. Dengan penurunan rasio tersebut menunjukkan keuangan perusahaan semakin solvabel untuk 
menutup hutang dengan modal yang dimilikinya.

2. Times interest earned ratio / Interest Coverage

E B I T

Times interest earned ratio $=$ x $100 \%$

Beban Bunga

Tabel 4

Perhitungan Times Interest Earned Ratio

\begin{tabular}{|c|c|c|c|}
\hline Tahun & EBIT & Beban Bunga & $\begin{array}{c}\text { Times Interest } \\
\text { Earned Ratio }\end{array}$ \\
\hline 2012 & 956.735 .765 & 538.973 .216 & 1,78 kali \\
\hline 2013 & 1.050 .765 .000 & 85.764 .650 & $12,25 \mathrm{kali}$ \\
\hline 2014 & 1.250 .825 .000 & 78.550 .425 & $15,92 \mathrm{kali}$ \\
\hline
\end{tabular}

Berdasarkan tabel 4 di atas menjelaskan perhitungan Times Interest Earned Ratio. EBIT tahun $2012 \mathrm{Rp}$ 956.735.765,- , tahun $2013 \mathrm{Rp}$ 1.050.765.000,- tahun $2014 \mathrm{Rp}$ 1.250.825.000,- . Beban bunga tahun 2012 Rp 538.973.216,- , tahun 2013 Rp 85.764.650,- , tahun 2014 Rp 78.550.425,-

Times Interest Earned Ratio ditahun 2013 mengalami peningkatan sebesar 10,47 kali dibandingkan tahun 2012 yang hanya 1,78 kali, sedangkan pada tahun 2014 mengalami kenaikan sebesar 3,67 kali jika dibandingkan dengan tahun 2013.
Hal ini disebabkan karena pada tahun 2013 terjadi penurunan EBIT sebesar Rp 94.029.235,- jauh lebih kecil dibandingkan dengan penurunan beban bunga yang sebesar Rp 453.208.566,- .

3. Rasio Utang atas Aktiva ( Total Debt to Total Assets Ratio )

Menurut Syahyunan (2004:84) merupakan rasio total kewajiban terhadap asset, dan rasio ini menekankan pentingnya pendanaan hutang dengan jalan menunjukkan presentase aktiva perusahaan yang di dukung oleh hutang.

$$
\text { Rasio Utang atas Aktiva }=\frac{\text { Total Hutang }}{\text { Total Aktiva }} \times 100 \%
$$


Tabel 5

Perhitungan Rasio Hutang Atas Aktiva

\begin{tabular}{|c|c|c|c|}
\hline Tahun & Total Hutang & Total Aktiva & Rasio (\%) \\
\hline 2012 & 302.713 .000 & 1.167 .670 .000 & 25,75 \\
\hline 2013 & 300.750 .000 & 1.291 .722 .000 & 26,34 \\
\hline 2014 & 329.775 .000 & 1.350 .625 .000 & 24,42 \\
\hline
\end{tabular}

Berdasarkan tabel .5 di atas menjelaskan perhitungan Rasio Hutang Atas Aktiva. Total Hutang tahun 2012 Rp 302.713.000,- , tahun 2013 Rp 300.750.000,- , tahun 2014 Rp 329.775.000,- . Total Aktiva tahun 2012 Rp 1.167.670.000,- tahun 2013 Rp 1.291.722.000,- tahun $2014 \quad \mathrm{Rp}$ 1.350.625.000,- .

Rasio hutang atas aktiva tahun 2012 sebesar 25,75\%, pada tahun 2013 sebesar 26,34\%, pada tahun 2014 sebesar 24,42 $\%$. Rasio pada tahun 2013 mengalami peningkatan sebesar $0,59 \%$ dibandingkan dengan tahun 2012. Sedangkan pada tahun 2014 rasio hutang atas aktiva mengalami penurunan sebesar $1,92 \%$.

Berdasarkan tabel di atas dapat dilihat bahwa Total Debt to Total Assets Ratio pada CV. Dunia Warna periode 2012-2014 menunjukkan perusahaan mampu menutup total hutang dengan aset yang dimilikinya.

\section{Rasio Rentabilitas/ Profitabilitas}

Rasio ini disebut juga sebagai Rasio Profitabilitas yaitu rasio yang digunakan untuk mengukur kemampuan perusahaan dalam memperoleh laba atau keuntungan dalam periode tertentu. Rasio ini digunakan untuk menilai seberapa efisien pengelola perusahaan dapat mencari keuntungan atau laba untuk setiap penjualan yang dilakukan. Profitabilias suatu perusahaan mewujudkan perbandingan antara laba dengan aktiva atau modal yang menghasilkan laba tersebut.

1. Net Earning Power Ratio/ Return on Invesmrnt (ROI)

Menurut Syahyunan (2011:85) merupakan rasio yang digunakan untuk mengukur kemampuan dari modal yang di investasikan dalam keseluruhan aktiva untuk menghasilkan keuntungan netto

$$
\text { Net Earning Power Ratio }=\frac{\text { Laba Bersih Setelah Pajak }}{\text { Total Aktiva }} \times 100 \%
$$


Tabel .6

Perhitungan Net Earning Power Ratio

\begin{tabular}{|c|c|c|c|}
\hline Tahun & Laba Bersih Setelah Pajak & Total Aktiva & Rasio (\%) \\
\hline 2012 & 142.891 .700 & 1.167 .670 .000 & 12,24 \\
\hline 2013 & 165.136 .900 & 1.291 .722 .000 & 12,78 \\
\hline 2014 & 180.650 .600 & 1.350 .625 .000 & 13,38 \\
\hline
\end{tabular}

Berdasarkan tabel .6 di atas dapat dilihat bahwa Net Earning Power Ratio menunjukkan bahwa perusahaan mampu menginvestasikan modalnya ke dalam keseluruhan aktiva untuk menghasilkan keuntungan.
2. Rate of Return for The Owner (Rasio Rentabilitas Modal Sendiri)

Menurut Syahyunan

(2011:85) merupakan kemampuan modal sendiri dalam menghasilkan laba bagi pemegang saham preferen atau saham biasa.

$$
\text { Rate of Return for the Owner }=\frac{\text { Laba Bersih Setelah Pajak }}{\text { Jumlah Modal Sendiri }} \times 100 \%
$$

Tabel 7

Perhitungan Rate of Return for the Owner

\begin{tabular}{|c|c|c|c|}
\hline Tahun & Laba Bersih Setelah Pajak & Total Modal Sendiri & Rasio (\%) \\
\hline 2012 & 142.891 .700 & 773.292 .000 & 18,48 \\
\hline 2013 & 165.136 .900 & 864.832 .000 & 19,10 \\
\hline 2014 & 180.650 .600 & 946.531 .000 & 19,09 \\
\hline
\end{tabular}

Berdasarkan tabel .7 di atas dapat dilihat bahwa Rate of Return for the Owner (Rasio Rentabilitas Modal Sendiri) pada perusahaan menunjukkan bahwa perusahaan mampu menghasilkan laba dari modal sendiri yang dimiliki karena rasio mengalami peningkatan dari tahun 2012 ke tahun 2013, walaupun pada tahun 2014 rasionya mengalami penurunan sebesar $0,01 \%$ dibandingkan dengan tahun 2013.

\section{Net Profit Margin Ratio}

Menurut Syahyunan

(2011:85) merupakan rasio yang digunakan untuk mengukur laba bersih sesudah pajak lalu di bandingkan dengan volume penjualan 


$$
\text { Net Profit Margin }=\frac{\text { Laba Bersih setelah Pajak }}{\text { Penjualan Bersih }} \times 100 \%
$$

Tabel .8

Perhitungan Net Profit Margin Ratio

\begin{tabular}{|c|c|c|c|}
\hline Tahun & Laba Bersih Setelah Pajak & Penjualan Bersih & $\begin{array}{c}\text { Rasio } \\
(\%)\end{array}$ \\
\hline 2012 & 142.891 .700 & 1.457 .000 .000 & 9,81 \\
\hline 2013 & 165.136 .900 & 1.505 .820 .000 & 10,97 \\
\hline 2014 & 180.650 .600 & 1.550 .325 .000 & 11,65 \\
\hline
\end{tabular}

Berdasarkan tabel 8 di atas Net Profit Margin Ratio CV. Dunia Warna mampu menghasilkan laba dari penjualan dalam periode tahun 2012-2014. Hal tersebut dapat di lihat dari rasionya pada tahun 2012-2014 yang mengalami kenaikan dari tahun ke tahun.

\section{Gross Profit Margin on Sales}

Gross Profit Margin on Sales $=$ Penjualan - HPP $\times 100 \%$

Penjualan

Tabel 9

Perhitungan Gross Profit Margin on Sales

\begin{tabular}{|c|c|c|c|}
\hline Tahun & Penjualan & HPP & $\begin{array}{c}\text { Gross Profit } \\
\text { Margin on Sales }\end{array}$ \\
\hline 2012 & 1.457 .000 .000 & 620.500 .000 & $57 \%$ \\
\hline 2013 & 1.505 .820 .000 & 775.250 .550 & $49 \%$ \\
\hline 2014 & 1.550 .325 .000 & 870.250 .000 & $44 \%$ \\
\hline
\end{tabular}


Berdasarkan tabel 9 di atas menjelaskan perhitungan Gross Profit Margin on Sales. Total Penjualan tahun $2012 \mathrm{Rp}$ 1.457.000.000,- , tahun 2013 sebesar Rp 1.505.820.000,- , tahun 2014 Rp 1.550.325.000,- .

Pada tahun 2012 perusahaan mempunyai Gross Profit Margin on Sales sebesar $57 \%$ artinya setiap Rp 1,- penjualan perusahaan dapat menghasilkan laba sebesar Rp 0,57,- .
Pada tahun 2013 perusahaan mengalami penurunan Gross Profit Margin on Sales sebesar $8 \%$ dibandingkan dengan tahun 2012, sedangkan pada tahun 2014 juga mengalami penurunan sebesar $5 \%$ dibandingkan dengan tahun 2013.

\section{Rasio Daya Laba Dasar (Basic Earning Power Ratio)}

$$
\text { Rasio BEP }=\underset{\text { E B I T }}{ } \times 100 \%
$$

Total Aktiva

Tabel .10

Perhitungan Rasio BEP

\begin{tabular}{|c|c|c|c|}
\hline Tahun & E B I T & Total Aktiva & Rasio BEP \\
\hline 2012 & 956.735 .765 & 1.167 .670 .000 & $82 \%$ \\
\hline 2013 & 1.050 .765 .000 & 1.291 .722 .000 & $81 \%$ \\
\hline 2014 & 1.250 .825 .000 & 1.350 .625 .000 & $93 \%$ \\
\hline
\end{tabular}

Berdasarkan tabel 10 di atas menjelaskan perhitungan Rasio BEP. Total EBIT tahun 2012 Rp 956.735.765,- tahun 2013 $\mathrm{Rp} \quad 1.050 .765 .000,-\quad$ tahun $2014 \mathrm{Rp}$ 1.250.825.000,- . Total Aktiva tahun 2012 Rp 1.167.670.000,- tahun $2013 \mathrm{Rp} 1.291 .722 .000,-$ tahun $2014 \mathrm{Rp} 1.350 .625 .000,-$.

Pada tahun 2012 BEP yang diperoleh 82 $\%$ artinya setiap $\mathrm{Rp} 1$,- total aktiva dapat mencapai total EBIT sebesar Rp 0,82,- . Pada 


\section{KESIMPULAN}

Berdasarkan pembahasan yang dilakukan pada bab sebelumnya, maka penulis dapat mengambil kesimpulan sebagai berikut :

\section{Current Ratio periode 2012-2014} perusahaan di atas $200 \%$ maka berarti aktiva lancar pada setiap tahunnya dapat menjamin seluruh hutang lancar yang di milikinya. Perusahaan dapat memenuhi kewajiban jangka pendeknya.

2. Quick Ratio yang dihasilkan perusahaan berada di atas $100 \%$, berarti aktiva lancar dikurangi persediaan dapat menjamin seluruh hutang lancarnya. Dengan quick ratio di atas $100 \%$ maka suatu perusahaan sudah bisa di katakan likuid.

3. Total Debt to Equity Ratio, Times Interest Earned Ratio, dan Total Debt to Total Capital Assets Ratio pada perusahaan ini mengalami kenaikan maka dapat di katakan perusahaan tersebut solvabel, karena perbandingan jumlah hutang dengan total modal dan total aktiva sangat tinggi, maka solvabilitas perusahaan sudah mampu untuk memenuhi kewajiban jangka panjang pada perusahaan tersebut.

4. Net Earning Power Ratio menunjukkan perusahaan mampu menginvestasikan aktiva, karena rasio mengalami peningkatan.

5. Rate of Return for the Owner menunjukkan bahwa perusahaan mampu menghasilkan laba dari modal sendiri yang dimiliki karena secara keseluruhan rasio mengalami peningkatan.

6. Net Profit Margin menunjukkan bahwa perusahaan mampu menghasilkan laba dari penjualan bersih, karena rasio mengalami peningkatan.

7. Gross Profit Margin on Sales menunjukkan bahwa perusahaan mampu menghasilkan sedikit laba dari penjualan,karena prosentase rasionya mengalami penurunan.

8. Basic Earning Power Ratio menunjukkan bahwa perusahaan dapat menciptakan EBIT dengan jumlah yang sedikit.

\section{SARAN}

Penulis akan memberikan saran yang dapat digunakan sebagai bahan pertimbangan untuk mengadakan perbaikan pada CV. Dunia Warna sesuai dengan apa yang telah penulis uraikan dalam tugas akhir ini. Dilihat dari posisi perusahaan dari tahun 2013 sampai dengan tahun 2014 perusahaan masih bisa meningkatkan kinerjanya agar posisi perusahaan dapat berada dalam kondisi aman. Saran yang dapat disampaikan adalah sebagai berikut :

1. CV. Dunia Warna untuk tahun yang akan datang hendaknya mengurangi hutang lancar dan memperbesar kenaikan kas. Sedangkan untuk Current Ratio dan Quick Ratio agar terus ditingkatkan sampai batas yang dianggap cukup baik perusahaan dalam memenuhi kewajiban jangka pendeknya.

2. Sebaiknya melakukan Manajemen Aset dengan baik, seperti manajemen kas, persediaan dan piutang dagang untuk mendapatkan hasil yang baik sekaligus dapat mengendalikan resiko.

3. CV. Dunia Warna untuk tahun yang akan datang agar mempertahankan tingkat persentase yang telah dicapai.

4. Hendaknya melakukan pengeluaran untuk pertumbuhan mendatang seperti mengadakan survei dan upaya penelitian untuk pengembangan produk yang dapat selalu disesuaikan dengan selera konsumen. 
5. CV. Dunia Warna untuk tahun yang akan datang agar lebih meningkatkan rentabilitas ekonomi karena selama ini rentabilitas ekonominya berada pada posisi rata-rata.

6. Sebaiknya diadakan penambahan fasilitas yang memadai sehingga dapat menunjang kinerja dan produksi yang di hasilkan dapat mengikuti perkembangan teknologi saat ini.

7. Untuk meningkatkan efektifitas dalam mengelola sumber dana yang dimiliki, perusahaan dapat melakukan dengan menempatkan dana tersebut ke dalam aktiva-aktiva yang mempunyai produktifitas tinggi, sehingga dapat diharapkan penjualan bersihnya meningkat. Dengan asumsi bahwa peningkatan penjualan bersih lebih tinggi bila dibandingkan dengan peningkatan total aktiva dan modal kerja, maka rasio yang dihasilkan akan semakin meningkat atau perputarannya semakin efektif.

8. Hendaknya melakukan hubungankerjasama yang baik dengan bank dengan melakukan manajemen hutang yang lebih baik.

9. Sebaiknya meningkatkan penjualan dan meminimalkan biaya-biaya yang dikeluarkan.

10. 10.Sebaiknya pada saat akhir tahun memberikan promosi khusus untuk menarik minat konsumen. 


\section{DAFTAR PUSTAKA}

Harahap, SofyanSyafri. (2008). Analisis Kritisatas Laporan Keuangan. Edisi ke 1. Jakarta: PT. Raja Grafindo Persada.

Kasmir.(2012). Analisis Laporan Keuanga. Edisike 1-5. Jakarta: Rajawali Pers.

Munawir, S. (2007). Analisa Laporan Keuangan. Edisike 4.Jakarta: Liberty.

Nuh, Muhammad. (2006). Principle Accounting. Jakarta: Fajar.

Purba,MarisiP.dan Andreas.(2005). Isu-isu Kontemporer Akuntansi Keuangan.Buku1. Jakarta: Natha Gemilang.

Revino.(2005). Manajemen Material. Jakarta: Djambatan.

Riyanto, Bambang. (2001). Dasar-dasar Pembelanjaan Perusahaan. Yogyakarta: BPFE.

Rudianto.(2006). Akuntansi Koperasi. Jakarta: PT Gramedia Widiasara Indonesia.
Samryn, L.M.(2002). Pengantar Akuntansi Manajerial. Jakarta: Raja Grafindo Persada.

Sawir,Agnes. (2005). Analisis Kinerja Keuangan dan Perencanaan Keuangan Perusahaan. Jakarta: PT Gramedia Pustaka Utama.

Soemarso S.R. (2004). Akuntansi Suatu Pengantar. Edisi ke 4. Yogyakarta: Rineka Cipta.

Sugiono, Arief dan Edy Untung. (2008). Panduan Praktis Dasar Analisa Laporan Keuangan. Jakarta: PT. Grasindo.

Sugiyarso, G., dan F.Winarni. (2006). Dasardasar Akuntansi Perkantoran. Yogyakarta : Media Pressindo.

Sumayang, Lalu. (2003). Dasar-dasar Manajemen Produksidan Operasi. Jakarta: Salemba Empat.

Supangkat, Harry. (2005). Buku Panduan Direktur Keuangan. Jakarta: Salemba Empat. 